\title{
FAKTOR YANG DIPERTIMBANGKAN KONSUMEN DALAM MELAKUKAN PEMBELIAN PRODUK PADA PT LONG TIME BATAM
}

\author{
Hendri Herman \\ Dosen Program Studi Manajemen, Universitas Putera Batam
}

email: hendrihermanbatam@gmail.com

\begin{abstract}
This study aims to look at the factors that influence consumer decisions in making purchases. The object of research is PT Long Time Batam, with a population of 135 people. calculation of the number of samples using the Slovin formula, so that the number of samples obtained is 100 respondents. from the results of the study note that the promotion has a significant influence on purchasing decisions. The effect of promotion on consumer decisions in making purchases is $42.2 \%$
\end{abstract}

Keywords: Promotion, Purchase Decision

\section{PENDAHULUAN}

Persaingan bisnins di Indonesia sat ini sangat ketat, sehingga menyebabkan setiap perusahaan berlomba-lomba untuk mencapai keunggulan untuk memperebutkan pangsa pasar. Jika perusahaan tidak memiliki keunggulan, maka perusahaan akan kalah dalam kegiatan usaha. Perilaku konsumen merupakan suatu kegiatan seseorang yang secara langsung terlibat untuk mendapatkan, mengkonsumsi suatu produk atau jasa, termasuk dalam pengambilan keputusan. Sehingga untuk menarik konsumen agar melakukan pembelian produk yang ditawarkan, maka perusahaan harus mengetahui keingina konsumen yang menjadi target pasar.

Terkait dena pesaingan perusahaan yang sangat ketat, maka perusahaan harus dapat meningkatkan kualitas produk, pelayanan, untuk membangun hubungan jangka panjang denga konsumen maupun calon konsumen. Hal ini akan membentuk loyalitas konsumen untuk mengkonsumsi atau menggunakan produk yang dihasilkan perusahaan.

Produk-produk yang ditawarkan perusahaan harus berorientasi pada kebutuhan dan keinginan konsumen. Keputusan pembelian konsumen merupakan keinginan dan tujuan akhir dari perusahaan agar produk laku terjual. Kebutuhan konsumen memang akan selalu berubahubah sesuai dengan selera konsumen itu sendiri. Akan tetapi, perusahaan harus dapat mampu untuk menyesuaikan dan menghasilkan produk yang dianggap akan mampu memenuhi kebutuhan, keinginan, dan kepuasan konsumen apabila telah menggunakan atau mengkonsumsi produk.

Konsumen, sebagai pelaku dalam memutuskan kegiatan pembelian adalah pihak yang harus dapat dipengaruhi oleh perusahaan agar mau melakukan pembelian produk. Perilaku konsumen merupakan proses pengambilan keputusan yang mensyaratkan aktivitas individu untuk mengevaluasi, memperoleh, menggunakan atau mengukur barang dan jasa

Keputusan konsumen dalam melakukan pembelian merupakan suatu keputusan yang telah melewati beberapa tahap sampai akhirnya konsumen mengambil keputusan untuk membeli atau tidak produk yang dijual. Dalam pengambilan keputusan pembelian sebuah produk ataupun jasa, konsumen memerlukan sebuah proses, yang mana proses in akan dipengaruhi oleh adanya 
keinginan dari konsumen dan juga terdapat pengaruh-pengaruh dari luar yang dapat mempengaruhi keputusa konsumen dalam melakukan pembelian.

Salah satu faktor yang dapat mempengaruhi keputusan konsumen dalam melakukan pembelian adalah promosi. Promosi yang dilakukan perusahaan dimaksudkan untuk memberikan pengenalan tentang produk kepada para calon konsumen maupun konsumen. Promosi harus dilakukan, terlebih lagi pada perusahaan-perusahaan baru atau produk baru. Kegiatan promosi ini dilakukan guna untuk meningkatkan penjualan. Melalui promosi, perusahaan mampu mempengaruhi konsumen agar membeli produk.

Perusahaan harus mampu melakukan kegiatan promosi semenarik mungkin, agar promosi yang dilakukan dapat menarik minat beli konsumen. Promosi merupakan suatu bentuk komunikasi pemasaran, yang dimaksud dengan komunikasi pemasaran adalah aktivitas pemasaran yang berusaha menyebarkan informasi, mempengaruhi atau membujuk, dan atau meningkatkan pasar sasaran atas perusahaan dan produknya agar bersedia menerima, membeli dan loyal pada produk yang ditawarkan perusahaan yang bersangkutan (Tjiptono, 2008).

Promosi memiliki manfaat yang besar untuk perkembangan perusahaan. Tanpa dilakukannya promosi maka masyarakat tidak akan mengenal produk, fungsi, serta manfaat poduk yang dihasilkan perusahaan. Dengan promosi, semua hal terkait dengan produk dapat sampai kepada masyarakat. Informasi tentang produk yang didapat melalui promosi inilah akan menjadi pertimbangan bagi calon konsumen dalam mengambil keputusan untuk membeli.

\section{TINJAUAN PUSTAKA}

\section{Promosi}

Promosi merupakan salah satu factor penentu keberhasilan suatu program pemasaran. Betapapun baiknya suatu produk atau jasa yang akan ditawarkan kepada konsumen, namun bila konsumen tersebut belum pernah mendengar ataupun belum merasakan produk atau jasa tersebut, mereka akan merasa tidak yakin bahwa produk atau jasa itu bermanfaat, maka akibatnya mereka tidak akan membeli atau menggunakannya.

Menurut (Kotler., 2009), promosi merupakan sarana yang digunakan perusahaan dalam upaya untuk menginformasikan, membujuk, dan menginatkan konsumen langsung atau tidak langsung tentang produk dan mereka yang mereka jual.

\section{Keputusan Pembelian}

Keputusan pembeian merupakan tindakan individu yang secara langsung atau tidak langsung terlibat dalam usaha memperoleh dan menggunakan suatu produk atau jasa yang dibutuhkan (Tjiptono, 2008). Sedangkan menurut (Kotler., 2009) keputusan pembelian pelanggan secara penuh merupakan suatu proses yang berasal dari semua pengalaman mereka dalam pembelajaran, memiliki, menggunakan, dan bahkan menyingkirkan suatu produk.

Proses keputusan pembelian merupakan sebuah proses dimana konsumen mengenal masalahnya, mencari informasi mengenai produk atau merek tertentu dan mengevaluasi seberapa baik masing-masing alternative tersebut dapat memecahkan masalahnya, yang kemudian mengarah kepada keputusan pembelian (Tjiptono, 2008)

\section{Promosi Terhadap Keputusan Pembelian}

Kegiatan promosi yang dilakukan oleh perusahaan bertujuan untuk memperkenalkan produk terhadap masyarakat. Jika promosi tidak dilakukan, maka akan sulit bagi perusahaan untuk menghasilkan penjualan yang tinggi untuk memperoleh keuntungan yang tinggi sehingga biaya operasional perusahaan dapat tertutupi. Karena pada hakikatnya, tujuan perusahaan melakukan promosi adalah untuk mempengaruhi konsumen agar melakukan pembelian pada produk yang dihasilkan oleh perusahaan. Seperti hasil penelitian yang dilakukan oleh menyatakan bahwa promosi berpengaruh signifikan terhadap keputusan pembelian (Katrin, Setyorini, \& Masharyono., 2016)

Berdasarkan tinjauan teoritis di atas, maka kerangka pemikiran dalam penelitian ini dapat digambarkan sebagai berikut: 


\begin{tabular}{|l|l|}
\hline Promosi & $\begin{array}{l}\text { Keputusan } \\
\text { Pembelian }\end{array}$ \\
\hline
\end{tabular}

Sejalan dengan kerangka pemikiran di atas, maka dapat ditarik hipotesis, yaitu: promosi berpengaruh secara signifikan terhadap keputusan pembelian.

\section{METODE}

Populasi adalah sekelompok orang, kejadian, sesuatu yang mempunyai karakteristik tertentu. Jika peneliti menggunakan seluruh elemen populasi menjadi data penelitian, maka disebut sensus, jika sebagian saja disebut sampel. Populasi mewakili karakteristik yang ingin didapatkan oleh penelitian dimaksud. Populasi adalah wilayah generalisi yang terjadi dari objek atau subjek yang menjadi kuantitas dan karakteristik tertentu yang ditetapkan oleh peneliti untuk dipelajari dan kemudian ditarik kesimpulannya, populasi sangat berkenan dengan data dan merupakan totalitas semua nilai yang mungkin, baik hasil hitung maupun pengukuran kuantitatif dan kualitatif pada karakteristik tertentu mengenai sekumpulan objek yang lengkap (Rumengan, 2013).

Populasi dalam penelitian ini sebanyak 135 orang, sampel dalam penelitian ini dihitung dengan menggunakan rumus slovin, sehingga didapat jumlah sampel sebesar 100 sampel. Teknik pengumpulan data menggunakan teknik penyebaran kuisioner kepada para pelanggan.

\section{HASIL DAN PEMBAHASAN \\ Uji Validitas Data}

Hasil uji validitas dalam penelitian ini dapat dilihat pada table berikut:

Tabel 1. Hasil Uji Validitas Promosi

\begin{tabular}{|l|l|l|l|l|}
\hline No & Item & R hitung & R tabel & Kesimpulan \\
\hline 1 & X.1.1 & 0.683 & 0.1966 & Valid \\
\hline 2 & X.1.2 & 0.688 & 0.1966 & Valid \\
\hline 3 & X.1.3 & 0.778 & 0.1966 & Valid \\
\hline 4 & X.1.4 & 0.757 & 0.1966 & Valid \\
\hline 5 & X.1.5 & 0.745 & 0.1966 & Valid \\
\hline
\end{tabular}

Berdasarkan tabel di atas, dapat dilihat bahwa nilai $r$ hitung masing-masing variabel promosi lebih besar dari nilai $r$ tabel (0.1966). sehingga dapat disimpulkan bahwa semua item dalam variabel promosi adalah valid.

Tabel 2. Hasil Uji Validitas Keputusan Pembelian

\begin{tabular}{|l|l|l|l|l|}
\hline No & Item & R hitung & R tabel & Kesimpulan \\
\hline 1 & Y.1 & 0,867 & 0.1966 & Valid \\
\hline 2 & Y.2 & 0,785 & 0.1966 & Valid \\
\hline 3 & Y.3 & 0,564 & 0.1966 & Valid \\
\hline 4 & Y.4 & 0,867 & 0.1966 & Valid \\
\hline
\end{tabular}

Berdasarkan tabel di atas, dapat dilihat bahwa nilai $\mathrm{r}$ hitung masing-masing variabel keputusan pembelian lebih besar dari nilai $r$ tabel (0.1966). sehingga dapat disimpulkan bahwa semua item dalam variabel keputusan pembelian adalah valid.

\section{Uji Reliabilitas}

Tabel 3. Hasil Uji Reliabilitas

\begin{tabular}{|l|l|l|l|}
\hline No & Variabel & Cronbach Alpha & Kesimpulan \\
\hline 1 & Promosi & 0.778 & Reliabel \\
\hline 2 & Keputusan pembelian & 0.770 & Reliabel \\
\hline
\end{tabular}

Berdasarkan tabel di atas, dapat dilihat bahwa masing-masing nilai cronbach alpha pada variabel promosi dan keputusan pembelian sebesar 0.778 dan 0.770 . nilai cronbach alpha ini lebih besar dari 0.6. sehingga disimpulkan bahwa item-item dalam variabel ini adalah reliabel. 


\section{Uji Asumsi Klasik}

Uji Normalitas

Uji normalitas dapat dilihat pada table berikut:

Tabel 4. Hasil Uji Normalitas

\begin{tabular}{|ll|r|}
\hline \multicolumn{2}{|c|}{ One-Sample Kolmogorov-Smirnov Test } \\
\hline $\mathrm{N}$ & $\begin{array}{c}\text { Standardized } \\
\text { Residual }\end{array}$ \\
Normal Parameters ${ }^{\mathrm{a}, \mathrm{b}}$ & Mean & 100 \\
& Std. Deviation & .0000000 \\
& Absolute & .99493668 \\
Most Extreme Differences & Positive & .088 \\
& Negative & .088 \\
Kolmogorov-Smirnov Z & & -.074 \\
Asymp. Sig. (2-tailed) & & .878 \\
\hline
\end{tabular}

a. Test distribution is Normal.

b. Calculated from data.

Dari tabel di atas, dapat dilihat bahwa nilai Asymp. Sig ( 2 tailed) memiliki nilai sebesar 0.424. nilai signifikansi ini lebih besar dari 0.05 , sehingga dapat disimpulkan seluruh data dalam penelitian ini telah terdistribusi secara normal.

\section{Uji Heteroskedastisitas}

Hasil uji heteroskedastisitas dapat dilihat pada scatter plot berikut ini:

Scatterplot

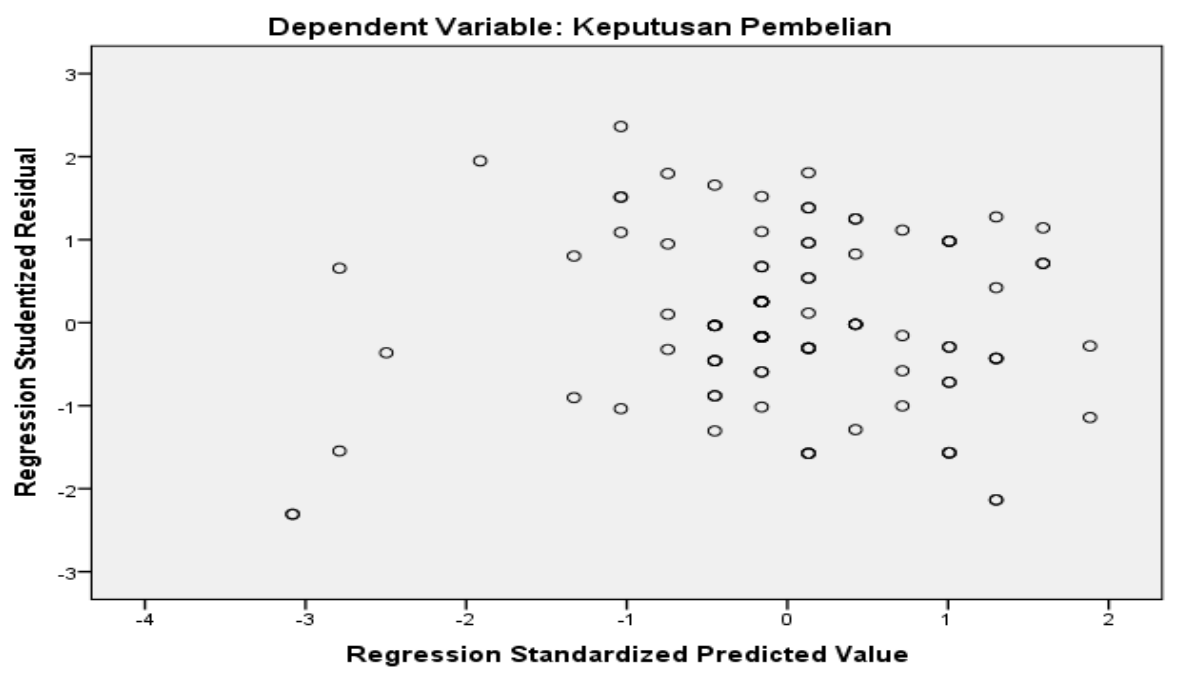

\section{Gambar 1. Scatter Plot}

Dari gambar di atas, dapat dilihat bahwa titik-titik telah menyebar di atas dan di bawah angka nol (0) pada sumbu Y, dan sebaran titik-titik tersebut tidak membentuk pola yang jelas, sehingga dapat disimpulkan bahwa data dalam penelitian ini tidak terjadi masalah heteroskedastisitas.

\section{Analisis Koefisien Determinasi}

Analisis koefisien determinasi dapat dilihat pada tabel berikut:

Tabel 5. Analisis Koefisien Determinasi

$$
\text { Model Summary }{ }^{\mathrm{b}}
$$

\begin{tabular}{|l|r|r|r|c|}
\hline Model & \multicolumn{1}{|c|}{$\mathrm{R}$} & $\mathrm{R}$ Square & $\begin{array}{c}\text { Adjusted } \mathrm{R} \\
\text { Square }\end{array}$ & $\begin{array}{c}\text { Std. Error of the } \\
\text { Estimate }\end{array}$ \\
\hline 1 & $.422^{\mathrm{a}}$ & .178 & .169 & 2.37855 \\
\hline
\end{tabular}

a. Predictors: (Constant), Promosi

b. Dependent Variable: Keputusan Pembelian 
Dari tabel di atas, dapat dilihat bahwa nilai R sebesar 0.422 atau sebesar 42,2\%. Hal ini menunjukkan bahwa promosi mempengaruhi keputusan pembelian sebesar $42,2 \%$, sedangkan sisanya sebesar $57,8 \%$ dipengaruhi oleh variabel lain yang tidak dimasukkan dalam penelitian ini

\section{Uji Hipotesis}

Uji Parsial (Uji t)

Hasil pengujian hipotesis pada penelitian dapat dilihat pada tabel berikut:

Tabel 6. Uji Parsial (Uji t)

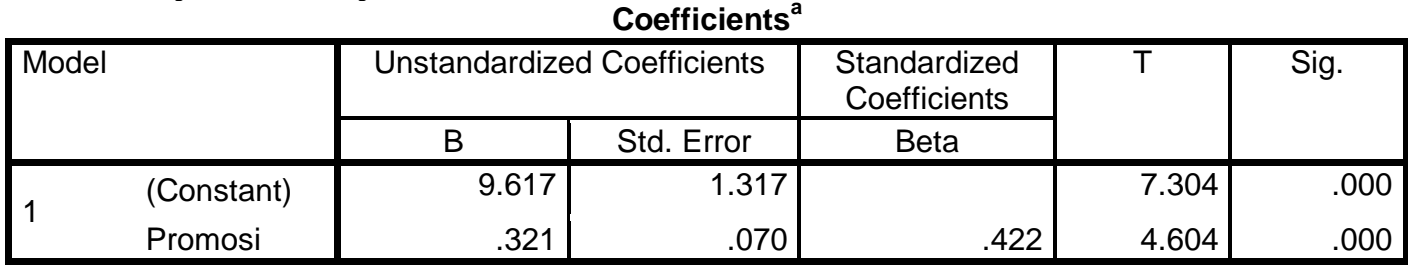

a. Dependent Variable: Keputusan Pembelian

Berdasarkan tabel di atas, dapat dilihat bahwa nilai signifikansi variabel promosi sebesar 0.000. Nilai signifikansi ini lebih kecil dari 0.05. sehingga dapat disimpulkan bahwa promosi berpengaruh signifikan terhadap keputusan pembelian. Maka hipotesis yang diajukan dalam penelitian ini diterima.

\section{Pembahasan}

1. Promosi berpengaruh signifikan terhadap keputusan pembelian

Dari hasil penelitian ini dinyatakan bahwa promosi berpengaruh signifikan terhadap keputusan pembelian. Promosi banyak memberikan pengaruh besar bagi penjualan perusahaan. Promosi yang dilakukan dengan tujuan untuk memperkenalkan produk kepada masyarakat, membujuk, serta mempengaruhi masyarakat untuk membeli produk perusahaan. Bahkan, banyak perusahaan yang rela untuk mengeluarkan biaya yang cukup besar dalam mempromosikan produknya agar dikenal masyrakat. Promosi yang dilakukan oleh perusahaan akan mempengaruhi tingkat penjualan perusahaan itu sendiri. Tidak akan mungkin, penjualan perusahaan akan meningkat jika perusahaan tidak melakukan kegiatan promosi. Bahkan, perusahaan besar saja masih melakukan promosi atas produk-produknya agar masyarakat tetap mengingat produk perusahaan.

\section{SIMPULAN}

Kesimpulan yang dapat diambil dari penelitan ini adalah:

1. Promosi berpengaruh signifikan terhadap keputusan pembelian konsumen

2. Pengaruh promosi terhadap keputusan konsumen dalam melakukan pembelian sebesar $42,2 \%$

\section{DAFTAR PUSTAKA}

Katrin, L. I., Setyorini, D., \& Masharyono. (2016). Pengaruh Promosi Terhadap Keputusan Pembelian di Restoran Javana Bistro Bandung. Gastronomy Tourism, 3(1), 246-254.

Kotler., K. (2009). Manajemen Pemasaran (12, Jilid). Jakarta: Indeks.

Rumengan, J. (2013). Metodologi Penelitian. Bandung: Ciptapustaka Media Perintis.

Tjiptono, F. (2008). Pemasaran Strategik. Yogyakarta: Andi. 